\title{
Zbornik Studies in Formal Slavic Linguistics - prispevki formalnih opisov slovanskih jezikov (Nova Gorica 2006)
}

\begin{abstract}
Andreja Žele
IZVLEČEK: Zbornik Studies in Formal Slavic Linguistics (v nadaljevanju FDSL-zbornik) obsega devetnajst angleško napisanih prispevkov in je še pisna predstavitev znanstvene konference Formalni opisi slovanskih jezikov oz. Formal Descriptions of Slavic Languages, ki je od 1. do 3. decembra 2006 potekala na Univerzi v Novi Gorici. Od enaintridesetih predstavljenih prispevkov jih je tu objavljenih devetnajst.

\section{The volume Studies in Formal Slavic Linguistics \\ Papers on Formal Descriptions of Slavic Languages}

ABSTRACT: The volume Studies in Formal Slavic Linguistics (hereinafter: the FDSL collection) contains nineteen articles in English and is the proceedings of the academic conference Formal Descriptions of Slavic Languages (Formalni opisi slovanskih jezikov), which took place from 1 to 3 December 2006 at the University of Nova Gorica. Nineteen of the thirty-one papers presented at the conference appear in this volume.
\end{abstract}

Studies in Formal Slavic Linguistics. Contributions from Formal Description of Slavic Languages 6.5. (Held at the University of Nova Gorica, December 1-3, 2006.) Eds. Franc Marušič, Rok Žaucer. Linguistik International 19. Frankfurt am Main, Berlin, Bern, Bruxelles, New York, Oxford, Wien: Internationaler Verlag der Wissenschaften Peter Lang GmbH, 2008. 354 str.

Zbornik Studies in Formal Slavic Linguistics (v nadaljevanju FDSL-zbornik) obsega devetnajst angleško napisanih prispevkov in je še pisna predstavitev znanstvene konference Formalni opisi slovanskih jezikov oz. Formal Descriptions of Slavic Languages, ki je od 1. do 3. decembra 2006 potekala na Univerzi v Novi Gorici. Od enaintridesetih predstavljenih prispevkov jih je tu objavljenih devetnajst.

Prispevki v angleščini opisujejo predvsem oblikoslovno-skladenjske in glasoslovne pojave $\mathrm{v}$ slovanskih jezikih in pristopi z izhodiščnim poudarkom na opisu in analizi oblik so kontrastivni. Ker pa so obravnavani slovanski jeziki, vključno s slovenščino, je prav in se navsezadnje tudi spodobi, da je vsaj odziv na zbornik napisan v slovenščini. 
Naslove izbranih skladenjskih obravnav $\mathrm{v}$ tej predstavitvi nisem prevajala, ker že nenatančni prevod lahko vnese brezpotrebne nejasnosti, zastranitve ali celo dezinformacije. Uvodoma torej predstavljam avtorje in članke z izvirnimi (angleškimi) naslovi - že to daje pomenljivo sliko o obsežnosti in različnosti zaobjetih vsebin in posledično seveda tudi predstavo o obsežnosti in različnosti obravnavane problematike: On Two Types of Negative Constituents and Negative Concord (Željko Bošković, 9-35), Restrictions on WH-Adjunct Movement in Serbian (Carlos de Cuba, Ivana Mitrović, 37-54), Decomposition of Nasal Vowels in Polish (Bartłomiej Czaplicki, 55-72), Argument Structure of Czech Event Nominals (Věra Dvořáková - Procházková, 73-90), Morphological Complexity and Obstruent Devoicing in Slovene (Alja Ferme, 91-102), Deriving Discontinuity (Steven Franks, 103-120), Russian Aspect as Bidirectional Optimization (Atle Grønn, 121-137), Bound to be Bound: on Certain Similarities between Pronominal and Anaphor Binding (Natalia Ivlieva, Alexander Podobryaev, 139-154), Double Definiteness Constructions in Colloquial Bulgarian (Vesselina Laskova, 155-172), Functional Generative Description, Restarting Automata and Analysis by Reduction (Markéta Lopatková, Martin Plátek, Petr Sgall, 173-190), The Interaction between Stress, Syntax and Meaning in Slovenian Priscianic Formations (Tatjana Marvin, 191-212), A Case Study of Predication (Ora Matushansky, 213-237), Reflexive Clitics, Movement and Layered Case (Lucie Medová, 239-254), Argument Structure in Russian Deverbal Nouns in -nie (Anna Pazelskaya, 255-272), Revising Involuntary State Constructions in Slovenian (María Luisa Rivero, Milena Milojević Sheppard, 273-289), Type Shifting and Lexical Semantics in the Interpretation of Russian Conjoined Relational Nouns (Peter, Staroverov, 291-308), Ordinary Property and Identifying Property WH-Words: Two kakoj-s in Russian (Igor Yanovich, 309-323), Why are Case Markers in the Czech Nominal Declension not Cyclic Suffixes (Markéta Ziková, 325-335), Varietes of Most: on Different Readings of Superlative Determiners (Sašo Živanović, 337-354).

V zvezi s tem lahko samo obžalujem, da uredništvo ni izkoristilo tudi priložnosti, da tak znanstveni dogodek, ki je bil tokrat pri nas, ob angleško objavljenih razpravah ne ponuja tudi krajših povzetkov razprav v slovenščini. To bi namreč imelo tudi čisto jezikoslovnopraktični smisel - slovenščina se prek različnih vsebinskih in usmeritvenih jezikoslovnih obravnav tudi strokovnoizrazno bogati. Tako pa zaenkrat tudi po objavi tega sicer vsebinsko bogatega in problemsko pomembnega zbornika za smer generativne oz. tvorbene slovnice ostajamo pri izrazju oz. si pomagamo s slovenskimi ustrezniki, ki sta jih v svojih strokovnih monografijah v slovenščini posredovala predvsem J. Orešnik in M. Golden.

Predvsem iz del slednje, tj. iz del M. Golden, kot sta O jeziku in jezikoslovju (Ljubljana, FF 22001) in Teorija opisnega jezikoslovja, 1 Skladnja (Ljubljana, FF 2001), povzemam nekaj najosnovnejših opredelitev in izhodišč tvorbene slovnice, ki so bistveni in potrebni za boljše izrazijsko-teoretično razumevanje razpravljalnega pristopa $\mathrm{v}$ člankih obravnavanega zbornika:

- Tvorbena slovnica je sistem prvin in pravil, je formalna, deduktivna teorija, v kateri jezikoslovec izdeluje model jezikovnega znanja govorca preučevanega jezika in jo s podatki rabe jezika preverja in popravlja. Osrednja ravnina tvorbene 
slovnice je skladenjska in ta bolj poudarja sestavniška kot odvisnostna razmerja; danes se v preučevanju jezikovnih pojavov osredinja na odkrivanje njihovih univerzalnih lastnosti.

- Tvorbena slovnica dopolnjuje in eksplicira opise tradicionalne in strukturalne slovnice, predvsem dodatno opozarja, da je treba razložiti tudi tiste lastnosti jezika, ki jih imamo v vsakdanji rabi jezika za samoumevne. Cilj tvorbene slovnice je izdelati teorijo jezikovnega znanja, tj. slovnico načel in parametrov; razlikuje se med univerzalnimi načeli naravnega človeškega jezika, za katera se domneva, da so vrojena, ter parametriziranimi načeli, ki so specifična za podmnožice jezikov.

- Tvorbenik sodbe govorca o sprejemljivosti (acceptability) izrek formalizira $\mathrm{v}$ napovedi o pravilni oblikovanosti (well-formedness), tj. slovničnosti (grammaticality) povedi. Sprejemljivost pripada preučevanju rabe jezika, »slovničnost« preučevanju jezikovne zmožnosti, vendar tako, da je slovničnost eden od dejavnikov, ki opredeljujejo, kaj je v rabi jezika sprejemljivo.

- Za prepričljivost jeziko/slo/vnega preučevanja $\mathrm{v}$ tvorbenem pristopu je poudarjeno upoštevanje zlasti treh zahtev - podatkovne ustreznosti (observational adequacy), opisne ustreznosti (descriptive adequacy) in razlagalne/pojasnitvene ustreznosti (explanatory adequacy).

V nadaljevanju bom nanizala nekaj bistvenejših ugotovitev, ki spodbujajo še dodatno primerjavo s slovenščino ali pa samo še potrjujejo pojave in trditve, že znane v slovenskem jezikoslovju. Že uvodoma so izpisani vsi avtorji in članki (z obsegom po straneh), tako da bo v nadaljevanju že iz navajanih strani razvidno, kateri članek je komentiran; načelno pa lahko poudarim, da so tu izbirno upoštevani, povzemani in pokomentirani predvsem članki s skladenjsko problematiko. Splošni pristopi tvorbene slovnice so uporabljeni pri opisu in razlagah posameznih skladenjskih pojavov, kot so npr.:

- Pogoji, zmožnosti in razmerja skladenjskopomenske rabe nihče/nič in kdorkoli/karkoli, predvsem glede na zanikane stavčne povedi - nihče ima veliko bolj zoženo skladenjskopomensko rabo, ker je tudi ožje vezana na zanikano povedje oz. na t. i. dvojno zanikanje sploh, npr. Ne želi nikogar videti / Nikogar ne želi videti (nasproti Ne želi, da bi kogar koli videl); v primeru kontrastivne srbohrvaško-angleške obravnave se primere niko označuje z ni-item in primere z iko z $i$-item. Čeprav se poudarja odločilnost prostega besednega reda, je premalo opozorjeno na (vsaj kdaj odločilni) vpliv členitve po aktualnosti, ki dopušča slovnično pravilno, vendar glede na izhodiščno poved spremenjeno skladenjskopomensko rabo, npr. Ona ne ljubi nikogar, Ona ne ljubi kogar koli, Ne želi nikogar/ničesar/nič videti, Ne želi kogarkoli/karkoli videti ipd.; na dopustnost oz. slovnično zmožnost določene rabe vsekakor vpliva izpustnost oz. eliptičnost in zato mora biti upoštevana, npr. Ona ne mara nikogar/ničesar/nič, Ona ne mara kogarkoli/karkoli ipd. $(18,29)$.

- O možnih skladenjskih premikih vprašalnic govorimo kot o izraženih skladenjskih vprašalnih k-premikih (wh-movement). Po nekem splošnem načelu so okoliščinske oz. prislovne vprašalnice levo od delovalniških oz. samostalniških vprašalnic, in tudi sicer med vprašalnicami velja neka hierarhija, npr. Kako si koga za kaj prepričal? Delovalniške vprašalnice so načeloma lahko zamenjajo tako za resnična kot za neresnična dopolnila, npr. Kaj znaš/obžaluješ ...?, Kaj verjameš ...?, 
okoliščinske vprašalnice pa so navadno zamenjava za neresnična dopolnila, npr. Zakaj verjameš ...? (nasproti npr. Zakaj znaš ...?); glede na valenco oz. vezljivost je odločilna tudi glagolska oz. povedkova izbirnost tako delovalniških kot okoliščinskih vprašalnic $(41,47,48)$.

- Pri obravnavi udeleženskosti velja, da isto udeležensko okolje obdržijo tudi samostalniki dejanj in procesov, izpeljani iz določenih glagolov; ohrani se tudi hierarhija udeleženskih vlog, ki je izražena tudi s hierarhijo sklonov, npr. rodilnikom (od katerih se osebkov popridevi v svojilni pridevnik), sledi orodnik, npr. sosedovo surovo pretepanje otrok in živine s palico. Tudi v pretvorbah se jasno ohranja oz. vzpostavlja razmerje med udeleženskimi določili in modifikacijskimi dopolnili, z dodatnim ohranjanjem predvsem vidskosti $(79,87)$.

- Pri povzročanju diskontinuitete besedila oz. pri rušenju koherentnosti besedila s prostimi morfemi ali s polnopomenskimi leksemi se zastavlja vprašanje, do katere mere je v posameznem jeziku to dopustno oz. tudi še logično, da se namreč $\mathrm{s}$ tem ne poruši smisel sporočanega; in do katere mere se lahko še govori o stilistični nevtralnosti ali zaznamovanosti znotraj funkcijskih zvrsti knjižnega jezika in kje se meja med skladenjsko nezaznamovanostjo in zaznamovanostjo že prevesi iz knjižnosti v pogovarjalnost, npr. Danes se mi ne ljubi govoriti : Danes se mi ne govori, Ne nastavljaj se pred mano : Ne nastavljaj se mi pred mano ipd. Umestno bi bilo vprašanje, ali je za jezike $\mathrm{z}$ deklarirano prosto stavo vrivanje različnih besed in besednih zvez zlasti stilno zaznamovano $(105,106,119)$.

- Uporaba elementov optimalnostne teorije je možna tudi v koherentni ruski teoriji vida. V razmerju rabe med dovršnikom in nedovršnikom so poudarjene zlasti posebne rabe kot npr. zanikani velelni dovršnik v primerih Čez deset minut bo že pozno. Pazi, ne zamudi! / Pazi, da ne zamudiš! (nasproti npr. Ne zamujaj, prosim!). Sicer je dovršnik informativno in smiselno močnejši kot nedovršnik. $Z$ vidika pomenskosti vida je poudarjeno bistvo besedilnih različic vida oz. odvisnost vida od sobesedila $(122,128,129,131,135)$.

- Opozorjeno je na konkretne dvoumnosti pri navezovanju oz. pri anaforični rabi zaimkov tipa Petrov učitelj ga je hvalil, Deklica ima rada njeno psičko (nasproti Deklica ima rada (lastno/svojo) psičko) ipd. Potrebno je preverjati navezovalne zmožnosti povratnih zaimkov in zaimkov sploh, npr. Peter je Pavlu prepovedal govoriti o sebi/njem, Skrbno je pogledal za sabo (nasproti npr. Zaskrbljeno je pogledal za njim); pri tem je pomembna oddaljenost anaforične zaimkovne navezave od odnosnice in pa odločitev, kateri izrazi v povedi morajo ostati nenavezani oz. neistovetni z nobeno drugo samostalniško zvezo $\mathrm{v}$ isti stavčni povedi. Zdi se, da je tudi $v$ teh primerih premalo poudarjena odločilna skladenjskopomenska vloga izbranih uporabljenih glagolov (143, 147, 153).

- Zveza določni členek ta + pridevnik je tipična za pogovarjalno zvrst jezika; v prispevku se ne razlaga samo kot stilistično zaznamovana raba, ampak tudi kot skladenjskorazločevalna raba v smislu, da se pri rabi Moj ta bivši mož je pjanc (v nasprotju z Moj bivši mož je pjanc) zaradi ta lahko še dodatno razume, da ima govoreča že drugega moža (168-170). Zlasti z vidika pogovarjalne slovenščine je koristna analiza različne možne skladenjskopomenske uporabe besed največ in večina $(338,339,347,353)$. 
- Pristop tvorbene slovnice s formalnimi in funkcionalnimi opisi se je pokazal kot uporaben za štiristopenjsko računalniško analiziranje z določeno stopnjo redukcije. Poudarjene in upoštevane so zahteve pomensko-skladenjske pravilnosti/ slovničnosti stavkov (correct sentences of the language LC), izrazna/formalna ravnina jezika (formal language LM) in možnost shematske pretvorbe (the relation by a sequence of translation schemes $\mathrm{SH}$ ) med jezikovnimi ravninami, pri čemer mora biti zagotovljena korektnost stavkov, lem, oblikoslovnih kategorij in vezljivostnih oz. vseh skladenjskih podatkov - slednje je še zlasti pomembno za slovanske jezike $z$ visoko stopnjo prostega besednega reda. Pri vsem naštetem je važno vključevanje teorije besednih zvez, teorije udeleženskih vlog, teorije sklona in teorij vezalnosti, navezovanja in omejevanja $(173,176,188)$.

- Tudi z vidika skladenjskega besedotvorja je koristna in pomenljiva razdelava primerov bralec : aretiranec - ti primeri s skupnim -ec na deležniški - $l$ in - $n$ teoretično združujejo besedotvorje, pomenotvorje in skladnjo (197, 210-211).

- Opozorjeno je tudi na različno skladenjskopomensko rabo besedice se v smislu različne stopnje vršilskosti in modalnosti, npr. Otrok se je končno trajno izročil staršem, Ani se je plesalo (240, 276).

Članki samo še dodatno potrjujejo, da je sodobna teorija opisnega jezikoslovja pomembna vzporednica in koristno dopolnilo že obstoječim uveljavljenim jezikoslovnim smerem v slovenskem prostoru. Kot je bilo že omenjeno, sem pogrešala prizadevanje vsaj nekaterih slovenskih avtorjev in pa seveda obeh urednikov zbornika, da bi opisanim jezikoslovnim pristopom dodali tudi slovenske jezikoslovne ustreznice, kar bi se (vsaj) deloma dalo narediti že z dodanimi kratkimi slovenskimi povzetki $\mathrm{k}$ sicer $\mathrm{v}$ celoti angleškim razpravam.

Na splošno pa sem med seznami literature na koncu člankov pogrešala navajanje uporabljenih korpusov in zbirk kot gradivnih virov, iz katerih so avtorji črpali uporabljane in obravnavane zglede.

Opazno je tudi kronično pomanjkanje slovenistične strokovne literature, kar je lahko problemsko zlasti v člankih, ki v kontrastivno-problemsko obravnavo vključujejo tudi slovenščino.

Vsekakor so tovrstni zborniki res idealna možnost in priložnost, da v svetovno jezikoslovje vključujemo ne samo slovenski prostor, ampak po najboljših močeh tudi slovensko jezikoslovje s slovenskim izrazjem.

Andreja Žele

Inštitut za slovenski jezik Frana Ramovša ZRC SAZU

Novi trg 2, 1000 Ljubljana

andrejaz@zrc-sazu.si 